\title{
Corrigendum
}

\section{Mahendraparvata: an early Angkor-period capital defined through airborne laser scanning at Phnom Kulen-CORRIGENDUM}

\author{
Jean-Baptiste Chevance, Damian Evans, Nina Hofer, Sakada Sakhoeun
}

\& Ratha Chhean

Published by Cambridge University Press, 15 October 2019

In this article, Figure 2 (top) was incorrectly attributed to the Archaeology Development Foundation. The correct attribution for Figure 2 (top) is (C) Erika Piñeros.

\section{Full citation}

Chevance, J.-B., D. Evans, N. Hofer,

S. Sakhoeun \& R. ChHean. 2019.

Mahendraparvata: an early Angkor-period capital defined through airborne laser scanning at Phnom Kulen. Antiquity 93: 1303-21. https://doi.org/10.15184/aqy.2019.133

(C) Antiquity Publications Ltd, 2020. This is an Open Access article, distributed under the terms of the Creative Commons Attribution licence (http://creativecommons.org/licenses/by/4.0/), which permits unrestricted reuse, distribution, and reproduction in any medium, provided the original work is properly cited. 